\title{
Analisis Semiotika Logo Brodo Footweardi Media Sosial Twitter (Studi Analisis Semiotika Roland Barthes)
}

\author{
Canditra Sultannata ${ }^{9}$, Siti Maryam ${ }^{10}$ \\ Universitas Pembangunan Nasional Veteran Jakarta \\ canditras@gmail.com, stmaryam65@ymail.com
}

\begin{abstract}
ABSTRAK
Seiring berkembangnya dunia periklanan, peran logo sangat penting sebagai identitas suatu produk. Tujuan Penelitian menganalisis makna logo Brodo Gentleman Footwear berdasarkan teori semiotika Roland Barthes Kajian Teoritis definisi konsep. Metode Penelitian yang digunakan adalah pendekatan kualitatif dengan jenis penelitian deskriptif. Pengumpulan Data dilakukan dengan melakukan depth interview, pengamatan dan studi pustaka. Hasil Penelitian menunjukan bahwa logo Brodo adalah teks ukiran Brodo dengan font yang membentuk silhouette ayam jago berwarna hitam dengan background putih. Tulisan Brodo begitu simple dan unik serta memberikan kesan kejantanan dan gagah yang berarti logo Brodo cukup menggambarkan identitas produk yang dijual, yaitu produk laki-laki yang gentlemen.kesimpulan: Logo Brodo ingin memperlihatkan bahwa logo tersebut cerminan dari pendiri Brodo, dan terdapat element fisik yang terdiri atas bentuk logo Brodo secara keseluruhan, Warna yang ada pada logo Brodo yaitu hitam dan putih, Teks yang terdapat di fisik logo yaitu "Brodo" yang dibuat menggunakan font gotham dan menggunakan warna dasar hitam pada tulisan Brodo dan warna putih pada background logo. Element non fisik dalam logo Brodo yang terdiri atas tujuan bahwa saat konsumen melihat logo tersebut akan selalu ingat cita rasa produk kebanggaan Indonesia, dan kegagahan produk Brodo. Dalam penelitian ini sesuai dengan teori semiotika Roland Barthes maka didapat makna yang terkandung dalam logo Brodo. Saran: Brodo dapat mempertahankan cita rasa fashion yang khas.
\end{abstract}

Kata Kunci:Semiotika, Logo, Twitter, Roland Barthes.

\section{ABSTRACT}

As the world of advertising develops, the role of logos is very important as the identity of a product. The aim of the study was to analyze the meaning of the

\footnotetext{
${ }^{9}$ Mahasiswa Program Studi Ilmu Komunikasi FISIP UPN Veteran Jakarta

${ }^{10}$ Dosen Program Studi Ilmu Komunikasi FISIP UPN Veteran Jakarta
} 


\section{PERSESPSI}

Volume 1 Nomor 1. Juli - Desember 2018

Brodo Gentleman Footwear logo based on Roland Barthes's semiotic theory Theoretical Study of concept definitions. The research method used is a qualitative approach with a type of descriptive research. Data collection is done by conducting depth interviews, observations and literature studies. The results of the study show that the Brodo logo is a Brodo engraved text with a font that forms a black rooster silhouette with a white background. Brodo's writing is so simple and unique and gives the impression of masculinity and dashing which means the Brodo logo is enough to describe the identity of the product being sold, namely the gentlemen's product. Conclusion: Brodo's logo wants to show that the logo is a reflection of Brodo's founder, consists of the shape of the Brodo logo as a whole, the colors that are in the Brodo logo are black and white, the text contained in the physical logo is "Brodo" which is made using Gotham fonts and uses a black base color on Brodo's writing and white on the background logo. The non-physical element in the Brodo logo consists of the goal that when consumers see the logo, they will always remember the taste of Indonesia's proud products, and the prowess of Brodo's products. In this study in accordance with Roland Barthes's semiotic theory, the meaning contained in the Brodo logo is obtained. Suggestion: Brodo can maintain a distinctive fashion taste.

Keywords: Semiotics, Logo, Twitter, Roland Barthes.

\section{PENDAHULUAN}

Asal kata logo dari bahasa Yunani "logos", yang berarti kata, pikiran, pembicaraan, akal budi. Pada awalnya yang lebih dulu populer adalah istilahlogotypebukanlogo. Pertama kali istilah logotype muncul tahun 1810-1840 diartikan sebagai tulisan nama entitas yang di design secara khusus dengan menggunakan teknik lettering atau memakai jenis huruf tertentu. Jadi awalnya logotype adalah elemen tulisan saja. Pada perkembangannya orang membuatnya makin unik/berbeda satu sama lain. Mereka mengolah huruf itu, menambahkan elemen gambar, bahkan tulisan dan gambar berbaur jadi satu, dan semua itu masih banyak yang menyebutnya dengan istilahlogotype.

Gagasan menggunakan tanda untuk menunjukkan hak kepemilikan bukanlah penemuan yang baru. Sejak abad ke-3, bangsa Mesopotamia dan Mesir menandai batu bata mereka dengan cap untuk menunjukkan bangunan milik mereka. Bahkan bangsa romawi menandai batu bata mereka dengan cap untuk menunjukkan siapa pembuatnya, tempat asal pembuatnya, dan tujuan dibuatnya 


\section{PERSERESSI}

batu bata tersebut. Logo pada awalnya memiliki bentuk yang sangat sederhana, yaitu berbentuk satu code yang terdiri dari sebuah huruf, kemudian menjadi sebuah design yang terdiri dari dua atau lebih huruf yang digabungkan (monogram). Code tersebut bisa saja semuanya terdiri dari huruf-huruf yang membentuk nama, inisial, atau nama depan dari seseorang untuk dipergunakan pada benda-benda pribadi, lambang kekuasaan, lambang agama, alat perdagangan, dan lain-lain. Bentuk awal logo dapat dilihat pada sebagian besar koin uang kuno Yunani dan Roma yang memiliki monogram atau logo dari penguasa/kota. Logo merupakan suatu bentuk gambar atau sekedar sketsa dengan arti tertentu, dan mewakili suatu arti dari perusahaan, daerah, perkumpulan, produk, negara, dan hal-hal lainnya yang dianggap membutuhkan hal yang singkat dan mudah diingat sebagai pengganti dari nama sebenarnya.

Logo merupakan suatu hal yang tidak terlepas dari produk, jasa, lembaga, maupun organisasi. Karena dari logo-lah produk, jasa, lembaga, dan organisasi dikenal oleh banyak masyarakat. Logo merupakan lambang-lambang yang menjadi ciri khas suatu produk untuk menandakan identitas dari produk itu sendiri. Peran logo menjadi amat penting seiring dengan berkembangnya dunia periklanan saat ini, terutama dalam identitas pembuatan strategi branding sebuah produk. Fungsi identitas merupakan ukuran sebuah logotype, dengan hanya melihat logo seseorang akan ingat, tertarik, lalu membeli. Biasanya, logo dirancang sesuai dengan filosofi yang dikehendaki oleh client. Selain itu, logo juga harus menggambarkan citra dan jenis usaha sesuai dengan tujuan client tersebut. Logo dengan gambaran citra yang diwakilinya dan terlihat menarik saat ini menjadi sebuah keharusan mengingat persaingan yang ketat. Salah satu fenomena logo adalah dengan hanya melihat logo, orang bisa tau produk apa yang dijual atau dipasarkan. Begitu dalamnya arti pada sebuah logo yang terkadang terlihat sederhana namun bisa diingat oleh seseorang. Terlihat jelas bahwa logo benar-benar menjadi identitas suatu produk maupun perusahaan dan sebagainya. Para ahli komunikasi mengungkapkan bahwa orang cendrung untuk mengingat 


\section{PERSEREPSI}

Volume 1 Nomor 1. Juli - Desember 2018

gambar lebih kuat dari teks (tulisan). Ketika orang melihat gambar yang menarik, mereka akan menyimpannya dalam ingatan lebih lama dari pada tulisan. Dalam ungkapan ini, dapat diartikan bahwa orang lebih cendrung dapat mengingat dengan baik sebuah logo yang diwakilkan dengan gambar yang menarik. Logo dibuat oleh designer logo yang harus memiliki pengetahuan luas dan memiliki kreatifitas. Proses pengaplikasian logo pada media-media yang akan dibuat, dibutuhkan konsistensi sebagai faktor penguat yang paling efektif dalam pembentukkansebuahidentitas. Sebuah logo sangatlah penting. Bukan hanya produk, jasa, maupun lembaga yang membutuhkan atau mempunyai logo, organisasi pun perlu memiliki sebuah logo untuk menunjukan identitas diri. Logo dibuat semenarik mungkin disertai dengan pemberian nama produk dengan katakata yang unik dan mudah diingat. Hal itu bertujuan agar produk atau jasa akan lebih mudah untuk diingat.

Melihat produk fasysen yang kian menjamur, seperti halnya produk feysen lokal di Indonesia, fenomena dimana logo menjadi identitas suatu produk menjadi fenomena yang menarik untuk diteliti lebih lanjut. Semakin banyaknya produk feysen yang ada, tentunya masing-masing produk fashion itu memiliki ciri khas sendiri. Produk sepatu lokal dari Brodo memiliki karakter yang sangat berbeda dari produk sepatu kebanyakan yang ada di Indonesia. Lahir dari rasa cinta sang pemilik dan pembuat sepatu Brodo terhadap Tanah Air Indonesia, setiap sepatu dari Brodo dibuat secara presisi. Mulai dari detail hingga pembuatannya, semuanya sangat lokal dengan kualitas terbaik buatan anak bangsa. Jadi, dengan setiap pasang sepatu, Brodo ingin siapapun yang menggunakan sepatu Brodo juga akan ikut merasa bangga dan berharap langkahnya juga menularkan kebanggaan terhadap bangsa Indonesia. Logo Brodo sendiri menggunakan teks. Teks tulisan "Brodo" dengan font terukir menggambarkan seekor ayam jago. Secara kasar, logo Brodo begitu gentlemen sesuai dengan produknya. 


\section{PEkspresi}

Untuk memperkenalkan loga tersebut, Brodo menggunakan berbagai media di antaranya twitter. Twitter merupakan sebuah situs website social media yang dimiliki dan dioperasikan oleh Twitter Inc. Twitter merupakan media sosial mikroblog sehingga memungkinkan penggunanya untuk mengirim dan membaca pesan yang disebut "tweet". Tweet adalah teks tulisan berjumlah 140 karakter yang ditampilkan pada halaman profile pengguna. Tweet bisa dilihat secara luar, namun pengirim dapat membatasi pengiriman pesan ke daftar teman-teman mereka saja. Selain itu, twitter mempunyai pilihan untuk memproteksi account twitter para penggunanya, agartweet mereka tidak dapat dilihat oleh sembarang orang. Twitter memiliki beberapa fiture andalan yang membuat twitter menjadi salah satu media sosial yang digemari oleh para penggiat internet. Berdasarkan hasil survei http://www.zocialrank.com.

Twitter hanya terbatas 140 karakter dalam postingannya sehingga memaksa Brodo membuat iklan yang singkat, padat, jelas namun langsung menuju dan sampai kepada target marketnya. Berdasarkan uraian pada latar belakang di atas maka pokok permasalahan yang dapat dirumuskan adalah: "Makna apa yang dimiliki logo Brodo Footwear di media sosial twitter menurut analisis semiotika Roland Barthes?”.Tujuan Penelitian Penelitian ini secara umum bertujuan untuk memberikan gambaran tentang semiotika logo Brodo Footwear. Secara khusus tujuan penelitian ini adalah untuk menganalisis makna dari logo Brodo gentlemen footwear berdasarkan teori semiotika Roland Barthes.

\section{KAJIAN LITERATUR}

Semiotika pada Sobur (2009, hlm. 16) berasal dari bahasa Yunani, semion yang berarti "tanda" atau "seme", yang berarti "penafsiran tanda". Semiotika berasal dari studi klasik dan skolastik atas seni logika, retorika dan poetika. "Tanda" pada masa itu masih bermakna sesuatu hal yang menunjuk pada adanya hal lain. Contohnya adalah asap yang menandakan adanya api. 


\section{PEkspresi}

Menurut Christomy dan Yuwono (2004, hlm. 87) semiotika adalah: "Sebuah cabang keilmuan yang memperlihatkan pengaruh semakin penting sejak empat dekade yang lalu, tidak saja sebagai metode kajian (decoding), akan tetapi juga sebagai metode penciptaan (encoding)".

Semiotika telah berkembang menjadi sebuah model sebagai suatu pembelajaran dari ilmu pengetahuan sosial yang memiliki unit dasar yang disebut tanda. Tanda terdapat dimana-mana ketika kita berkomunikasi dengan orang, memakai pakaian, makan, minum, dan ketika berbicara. Pada umumnya tanda mengandung 2 (dua) bentuk. Pertama tandamenjelaskan (baik secara langsung maupun tidak langsung) tentang sesuatu dengan makna tertentu. Kedua, tanda mengkomunikasikan maksud suatu makna.

Menurut Fiske (Sobur 2009, hlm.94)terdapat tiga area penting dalam studi semiotika, yakni:

a) Tanda itu sendiri. Hal ini berkaitan dengan beragam tanda yang berbeda, seperti cara mengantarkan makna serta cara menghubungkannya dengan orang yang menggunakannya. Tanda adalah buatan manusia dan hanya bisa dimengerti oleh orang-orang yang menggunakannya.

b) Kode atau sistem dimana lambang-lambang disusun. Studi ini meliputi bagaimana beragam kode yang berbeda dibangun untuk mempertemukannya dengan kebutuhan masyarakat dalam sebuah kebudayaan.

c) Kebudayaan dimana kode dan lambang beroperasi.

Sebuah logodapat dianalisis berdasarkan semiotikamenggunakaneori dari: a) Charles Sanders Peirce b) Ferdinand de Saussure c) Umberto Eco d) Roland Barthes. Berdasarkan penjelasan di atas, dalam menganalisis logo Brodo Footwear peneliti menggunakan teori dari Roland Barthes. Sebab, Roland Barthes mengartikan tanda sebagai suatu unsur budaya. Sedangkan di dalam logo Brodo Footwear terdapat unsur kebudayaan yaitu penggunaan nama brand "Brodo". Nama "bro", yang berarti "brother" merupakan sebuah panggilan kepada saudara laki-laki dari kebudayaan yang ada di luar negeri dan panggilan dengan nuansa positif bagi orang yang baru saling kenal. 


\section{PERSERESI}

Menurut Kriyantono (2012, hlm.272), Gagasan Roland Barthes ini dikenal dengan "Order OfSignification”.Tatanan pertanda (Order Of Signification)terdiri dari:

a) Denotasi Makna kamus dari sebuah kata atau terminologi atau objek (literal meaningof a term or object). Ini adalah deskripsi dasar. Makna denotatif dari "Big Mac" adalah sandwich yang dibuat oleh McDonalds yang dimakan dengan saus tomat atau sambal.

b) Konotasi Makna-makna kultural yang melekat pada sebuah terminologi (the cultural meaning thats become attached to a term). "Big Mac" dari McDonald di atas dapat mengandung makna konotatif bahwa orang Amerika itu identik dengan makanan cepat saji, keseragaman, mekanisasi makanan, kekurangan waktu, tidak tertarik masakan.

c) Metafora Mengkomunikasikan dengan analogi. Contoh metafora yang di dasarkan pada identitas "cintaku adalah mawar merah". Artinya mawar merah digunakan untuk menganalogikansebuahcinta.

d) Simile Subkategori metafora dengan menggunakan kata-kata "seperti". Metafora berdasarkan identitas (cintaku = mawar merah), sedangkan simile berdasarkan kesamaan (cintaku seperti mawar merah).

e) Metonimi Mengkomunikasikan dengan asosiasi. Asosiasi tersebut dibuat dengan cara menghubungkan sesuatu yang kita ketahui dengan sesuatu yang lain. Contoh: Mobil Roll Royce di asosiasikan dengan "kekayaan", karena kita tahu bahwa harga mobil tersebut sangatlahmahal.

f) Synecdoche Subkategori metonimi yang memberikan makna "keseluruhan" atau "sebaliknya". Artinya, sebuah bagian digunakan untuk mengasosiasikan keseluruhan bagian tersebut. Contoh: Gedung Putih identik dengan "kepresidenan Amerika", Pentagon identik dengan militer "Amerika". Kita tahu bahwa Gedung Putih adalah nama kantor dan kediaman resmi Presiden Amerika Serikat, sedangkan Pentagon adalah nama kantor departemen pertahanan Amerika Serikat.

g) Intertextual Hubungan antara teks (tanda) dan dipakai untuk memperlihatkan bagaimana teks saling bertukar satu dengan yang lain, sadar ataupun tidak sadar. Parodi merupakan contoh intertextual di mana sebuah teks (perilaku seseorang misalnya) meniru perilaku orang lain dengan maksud humor.

\section{Model Analisis Roland Barthes}

Pada sebuah metode analisis, terdapat beberapa model pendekatan yang dapat dilakukan untuk melakukan sebuah analisis semiotika, sedangkan model pendekatan yang digunakan dalam penelitian ini adalah model analisis semiotika yang dikembangkan oleh Roland Barthes. Menurut Kurniawan (2001, hlm. 14) tanda adalah: "Kesatuan dari suatu bentuk penanda (signifier) dengan sebuah ide atau petanda (signified)". 


\section{PERSEREPSI}

Volume 1 Nomor 1. Juli - Desember 2018

Dengan kata lain, penanda adalah "bunyi yang bermakna" atau "coretan yang bermakna". Jadi, penanda adalah aspek material dari bahasa yaitu apa yang dikatakan atau didengar dan apa yang ditulis atau dibaca. Petanda adalah gambaran mental, pikiran, atau konsep. Jadi, petanda adalah aspek mental dari bahasa".

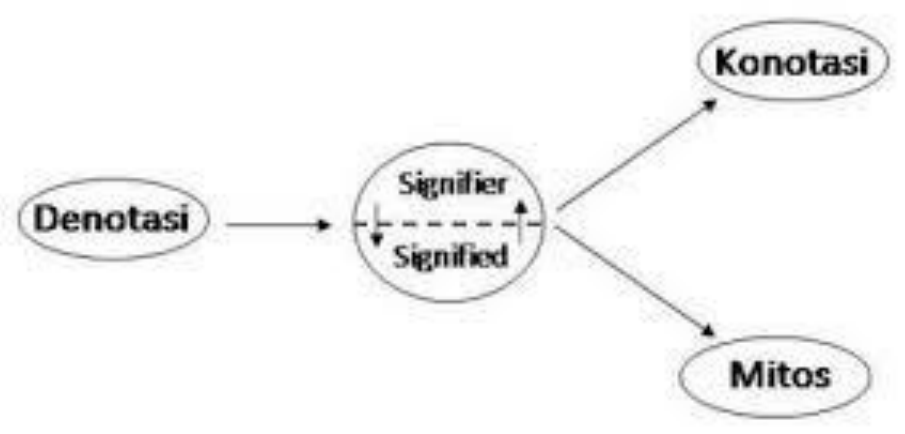

Gambar 1.Elemen Makna dari Barthes(Two Order of Signification)

Melalui model tersebut Barthes menjelaskan bahwa signifikasi tahap pertama merupakan hubungan signifier (ekspresi) dan signified (content) di dalam sebuahtanda terhadap realitasexternal.Itulah yang disebut Barthes sebagai denotasi yaitu makna paling nyata dari tanda (sign). Konotasi adalah istilah yang digunakan Barthes untuk menunjukkan signifikasi tahap dua. Tanda konotatif tidak sekadar memiliki makna tambahan namun juga mengandung kedua bagian tanda denotatif yang melandasi keberadaannya. Pada dasarnya, ada perbedaan antara denotasi dan konotasi dalam pengertian secara umum serta denotasi dan konotasi yang dipahami oleh Barthes. Konotasi bekerja dalam tingkat subjektif sehingga kehadirannya tidak disadari. Pembaca mudah sekali membaca makna konotatif sebagai denotatif.

Di dalam semiologi Barthes dan para pengikutnya, denotasi merupakan sistem signifikasi tingkat pertama, sementara konotasi merupakan tingkat kedua. Dalam hal ini denotasi justru lebih di asosiasikan dengan ketertutupan makna. 


\section{PERSERESSI}

Sebagai reaksi untuk melawan keharfiahan denotasi yang bersifat opresif ini, Barthes mencoba menyingkirkan dan menolaknya. Baginya yang ada hanyalah konotasi. Ia lebih lanjut mengatakan bahwa makna "harfiah" merupakan sesuatu yang bersifat alamiah. Dalam kerangka Barthes, konotasi identik dengan operasi ideologi, yang disebutnya sebagai 'mitos' dan berfungsi untuk mengungkapkan dan memberikan pembenaran bagi nilai-nilai dominan yang berlaku dalam suatu periode tertentu.

Di dalam mitos juga terdapat pola tiga dimensi (3D) penanda, petanda, dan tanda. Namun sebagai suatu sistem yang unik, mitos dibangun oleh suatu rantai pemaknaan yang telah ada sebelumnya atau dengan kata lain, mitos adalah juga suatu sistem pemaknaan tataran kedua. Di dalam mitos pula sebuah petanda dapat memiliki beberapa penanda. Pada signifikasi tahap kedua yang berhubungan dengan isi, tanda bekerja melalui mitos (myth). Mitos adalah bagaimana kebudayaan menjelaskan atau memahami beberapa aspek tentang realitas atau gejala alam. Mitos Roland Barthes muncul dikarenakan adanya persepsi dari Roland Barthes sendiri bahwa di balik tanda-tanda tersebut terdapat makna yang misterius yang akhirnya dapat melahirkan sebuah mitos. Jadi intinya bahwa mitos-mitos yang dimaksud oleh Roland Barthes tersebut muncul dari balik tanda-tanda dalam komunikasi sehari-hari, baik tertulis maupun melalui media cetak.

\section{Logo}

Menurut Suyanto (2006, hlm.159) merupakan "Suatu identitas brand yang mengkomunikasikan secara luas tentang produk, pelayanan dan organisasi dengan cepat. Logo tidak sekedar suatu label, tetapi menampilkan pesan kualitas dan semangat produk, salah satunya lewat pemasaran, periklanan, dankinerja produk". Sedangkan menurut Juju (2007, hlm.1)logoadalah:

Sebuah identitas atau brand yang dimiliki suatu perusahaan atau suatu bentuk usaha. Logoyang biasa dibuat ada yang berupa text baseddata juga yang berupa picture based. Logo yang berupa text based adalah logo yang dibentuk 


\section{PERSERESI}

hanya oleh huruf yang divariasikan atau dibuat unik. Yang termasuk dalam logo text based seperti coca-cola, IBM, nokia, google, dan lain-lain. Sedangkan logo yang berupa picture based merupakan bentuk logo yang menjadikan picture atau image sebagi ciri utamanya, misalnya PLN, pertamina, dan lain-lain. Selain itu, biasanya logo memiliki filosofi atau arti tersendiri bagi yang membuatnya (designer).

Logo dapat di ibaratkan dengan wajah. Setiap orang dapat dengan mudah dikenali antara satu dengan yang lain hanya dengan melihat wajah. Begitu pun logo. Logo merupakan sebuah visi penyampaian citra positif melalui sebuah tampilan sederhana dalam bentuk simbol. Karena fungsi dasarnya sebagai identitas. Logo haruslah unik dan mudah diingat. Logo dapat berupa nama, lambang atau element grafis lain yang ditampilkan secara visual. Logo juga harus di visualisasikan seimbang dan enak dipandang, serta relevant sehingga mampu memberikan penjelasan mengenai apa yang ditawarkan perusahaan pemilik logo.

\section{Twitter}

Domikus Juju \& Matamaya Studio(2009, hlm. 2-3) twitter “Adalah sebuah web dan layanan mikroblog yang bisa digunakan untuk melakukan pembaharuan (update) berupa sebuah teks panjang maksimum sebanyak 140 karakter, pembaharuan (update) di twitter dikenal sebagai tweets".

Penggunaan twitter telah menciptakan banyak fungsi menurut Dominikus Juju dan Mata Maya Studio (2009, hlm. 3). Secara garis besar fungsifungsi tersebut yaitu:

a) Untuk menuliskan bebagai hal yang ingin ditulis tidak mewajibkan untuk menulis apa yang sedang dilakukan, dapat menuliskan apa saja mengenai perasaan anda.

b) Bisa digunakan untuk berbagi (share)foto, lagu, danvideokepada temanteman.

c) Mencari teman-teman baru di dunia maya.

d) Bisa mengetahui kebiasaan apa saja yang dilakukan oleh public figure.

e) Mempopulerkanwebataublogyang dimliki dengan cara berbagi tautan(link)article yang dibuat padatwitter.

f) Bisa digunaan sebagai media advertisesecara tidak langsung.

g) Bisa digunakan untuk mencari dukungan politik atau kampanye di dunia maya. 


\section{PERSEREPSI}

Volume 1 Nomor 1. Juli - Desember 2018

h) Bisa digunakan sebagai media informasi secara realtime, seperti memberikan informasi mengenai suatu bencana atau kejadian tertentu.

i) Bisa digunakan untuk berbisnis.

\section{Design Grafis}

Menurut Suyanto (2004, hlm. 27)dapat didefinisikan sebagai: “Aplikasi dari keterampilan seni dan komunikasi untuk kebutuhan bisnis dan industri (yang biasanya disebut seni komersil). Aplikasi-aplikasi ini dapat meliputi periklanan dan penjualan produk, menciptakan identitas visual untuk institusi, produk dan perusahaan, dan lingkungan grafis, desain informasi, dan secara visual menyempurnakan pesan dalam publikasi. Sebuah design dapat cukup efektif jika mempengaruhi perilaku".

Design logo Brodo yang merupakan bentuk teks tulisan membentuk seperti ayam jago, telah memenuhi tujuan dibuatnya design grafis. Yaitu, sebagai identitas Brodo Footwear itu sendiri, dan mudah diingat apabila digunakan untuk berkampanye atau promosi.

\section{METODE PENELITIAN}

peneliti menggunakan metode kualitatif. karena ingin mengetahui tentang pemaknaan dalam arti logo produk sebagai identitas dan promosi produk tersebut ke masyarakat. Sebab, logo perusahaan atau organisasi termasuk bagian dari promosi. Data yang digunakan dalam penelitian data yang bersifat deskriptif, lebih ditekankan persoalan kedalaman (kualitas) data. Peneliti menggunakan metode kualitatif untuk mengetahui tentang pemaknaan logo produk sebagai identitas produk. Datanya bersifat deskriptif, dilakukan dengan wawancara mendalam dan participant observation. Jenis Penelitian yang digunakan ini adalah kualitatif interpretatif, peneliti melakukan pengamatan secara menyeluruh dari semua tanda dalam logo Brodo Footwear, termasuk bentuk gambar dalam produk tersebut. Peneliti melakukan interpretasi-interpretasi terhadap tandatanda untuk kemudian dimengerti, dipahami dan dimaknai, memfokuskan pada 


\section{PERSEREPSI}

Volume 1 Nomor 1. Juli - Desember 2018

tanda dalam logo Brodo Footwear serta bagaimana peneliti menafsirkan arti dari logo tersebut.

langkah-langkah analisis semiotika yang dilakukan oleh peneliti sebagai berkut : a. Mengidentifikasi tanda-tanda yang terdapat dalam logo Brodo Footwear. b. Menginterpretasikan satu per satu tanda yang telah di identifikasi dalam logo tersebut. c. Memaknai secara keseluruhan mengenai logo sebagai media Publisitas atau bentuk identitas dalam logo produk fashion lokal Brodo Footwear berdasarkan hasil interpretasi terhadap tanda, objek dan interpretasi yang telah diidentifikasi sebelumnya.Unit Analisis Data Unit data yang akan diteliti dalam hal ini adalah mengenai makna bentuk logo Brodo Footwear yang menjadi objek pengamatan, yang dibagi berdasarkan tulisan dan lambang pada logo tersebut.

Teknik Keabsahan Data digunakan Triangulasi untuk menguji keabsahan data, Triangulasi Metode yaitu menggunakan dua metode atau lebih untuk meneliti suatu hal, seperti metode wawancara dan metode analisis yang ditunjang dengan metode wawancara.

\section{PEMBAHASAN}

Berdasarkan Analisis Roland Barthes Barthes merumuskan tanda sebagai sistem yang terdiri dari expression yang berkaitan (relation R) dengan secara terperinci, Barthes dalam bukunya Mythology menjelaskan bahwa sistem signifikasi tanda terdiri atas relasi $(\mathrm{R}=$ relation)antara tanda $(\mathrm{E}=$ expression $)$ dan $(\mathrm{C}=$ conten $)$. Teori tanda tersebut dikembangkannya dan ia menghasilkan teori denotasi dan konotasi.

Tanda di dalam logo Brodo Footwear memiliki makna tersendiri bagi pembuatnya. Dimana logo biasanya memiliki filosofi bagi perusahaan dan produk yang dijual. Dalam logo Brodo Footwear peneliti juga meneliti makna logo tersebut bagi konsumen Brodo Footwear. Peneliti memberikan pertanyaan kepada konsumen Brodo Footwear. Kriteria konsumen yang peneliti berikan 


\section{PERSERESSI}

pertanyaan adalah konsumen yang menanggapi iklan, konsumen yang kurang menanggapi iklan, dan konsumen yang tidak menanggapi iklan. Alasan peneliti hanya memberikan pertanyaan kepada tiga orang kosumen karena peneliti menganggap ketiga orang ini mampu memberikan penjelasan secara mendalam tentang simbol-simbol dalam logo Brodo Footwear. Selain itu dengan kriteria sering berkunjung, tidak terlalu sering, dan jarang akan dapat diketahui sejauh mana pemaknaan logo Brodo Footwear bagi konsumen. Berikut ini adalah pembahasannya.

Brodo berasal dari bahasa Italia yang artinya kaldu. Kaldu berarti bumbu yang dimetaforasikan sebagai sepatu, yaitu bumbu berpenampilan. Di bawah ini adalah penjelasan analisis semiotika Roland Barthes yang peneliti gunakan untuk menganalisis logo BrodoFootwear.

\section{a. Teks padaLogoBrodo}

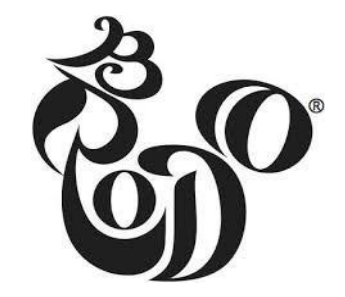

Sumber: google

\section{Gambar1.Teks Brodo Footwear}

Tabel 1.Teks

\begin{tabular}{|c|l|rl|}
\hline Denotasi & \multicolumn{1}{|c|}{ Konotasi } & \multicolumn{1}{c|}{ Mitos } \\
\hline $\begin{array}{c}\text { Teks tulisan } \\
\text { Brodo }\end{array}$ & $\begin{array}{l}\text { 1. Penerjemah makna } \\
\text { 2. Penjelasan suatu } \\
\text { tanda }\end{array}$ & 1. & $\begin{array}{l}\text { Tulisan } \\
\text { mencerminkan } \\
\text { panggilan }\end{array}$ \\
& $\begin{array}{l}\text { 3. Penandaan suatu } \\
\text { benda } \\
\text { atau mahkluk }\end{array}$ & 2. & $\begin{array}{l}\text { Dapat mewakili } \\
\text { identitas perusahaan }\end{array}$ \\
& 3. & 3. Tanda \\
\hline
\end{tabular}

Menurut Eko Suharjanto (konsumen yang menanggapi iklan), teks tulisan Brodo mempunyai makna identitas Brodo sebagai produk footwear laki- 


\section{PERSEREPSI}

Volume 1 Nomor 1. Juli - Desember 2018

laki yang terlihat simple dan tidak terlalu banyak atribut. Sedangkan menurut Sobri Ikhsan (konsumen yang kurang menanggapi iklan), teks tulisan Brodo ini hanyalah sebuah logo yang memiliki makna simple sebagai toko yang menjual produk lakilaki. Menurut Rizky Ristianto (konsumen yang tidak menanggapi iklan), teks tulisan Brodo merupakan gambaran dari produk yang di jual. Produk laki-laki yangsimple.

Menurut pembuat logo, Brodo berasal dari bahasa Italia yang artinya kaldu. Kaldu berarti bumbu yang dimetaforasikan sebagai sepatu, yaitu bumbu berpenampilan. Bumbu dalam fashion yang mempercantik dalam berpenampilan. Secara pengucapan, Brodo dapat diucapkan dengan mudah. Brodo memiliki banyak makna turunan seperti Bro-Do, Brothers who do, meskipun tidak menggunakan bahasa Indonesia, namun spirit yang dibawa adalah nasionalispatriotis-romantik.

Teks dibuat membentuk silhouette ayam jago dengan menggunakan kaidah men-design logo,dari manual hingga komputerisasi. Berdasarkan pernyataan di atas maka dapat dikatakan bahwa teks Brodo mempresentasikan tentang filosofi Brodo yang di ambil dari bahasa Itali dengan arti kaldu. Maksud dari kaldu adalah mengisyaratkan produk yang dijual Brodo memiliki cita rasa yang baik. Dan teks memperlihatkan kesederhanaan sehingga dapat mempresentasikan produk-produk yang dijual sebagai produk yang diinginkan semua pria, produk yang simple namun elegant.

\section{b. Bentuk pada Logo Brodo}

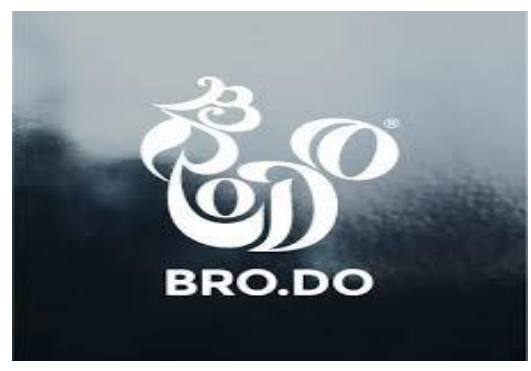

Sumber: google 


\section{PERSERESI}

Volume 1 Nomor 1. Juli - Desember 2018

Gambar2 .Bentuk UkiranBrodoFootwear

Tabel 2.Ukiran

\begin{tabular}{|l|l|ll|}
\hline \multicolumn{1}{|c|}{ Denotasi } & \multicolumn{1}{|c|}{ Konotasi } & \multicolumn{1}{c|}{ Mitos } \\
\hline $\begin{array}{l}\text { Ukiran bentuk ayam } \\
\text { jago }\end{array}$ & 1. $\begin{array}{l}\text { Ukiran bentuk ayam } \\
\text { jago dikonotasikan } \\
\text { sebagai image dari } \\
\text { produk yang dijual; } \\
\text { image gentlemen. }\end{array}$ & 1. $\begin{array}{l}\text { Ukiran melambangkan } \\
\text { keindahan }\end{array}$ \\
& 2. $\begin{array}{l}\text { 2. Ayam jago selalu } \\
\text { terlihat gagah karena } \\
\text { 2. Ukiran bentuk ayam } \\
\text { jagi dikonotasikan juga } \\
\text { sebagai perusahaan } \\
\text { yang rajin bagai ayam } \\
\text { yang selalu bangun } \\
\text { pagi untuk mencar }\end{array}$ & 3. $\begin{array}{l}\text { 3. Ayam biasa menjadi } \\
\text { lambang mak }\end{array}$ \\
& & \\
\hline
\end{tabular}

Soal ukiran bentuk ayam jago, menurut Eko Suharjanto (konsumen yang menanggapi iklan) memiliki makna ayam jago adalah ayam yang gagah karena sering menjadi ayam yang diindikasikan sebagai jagoan dan tangguh. Sobri Ikhsan (konsumen yang kurang menanggapi iklan), bentuk ayam jago melambangkan ayam jantan. Dimana ayam jantan merupakan ayam laki-laki dan sesuai dengan produk Brodo. Karena menciptakan produk untuk laki-laki, maka harus gentlemen. Menurut Rizky Ristianto (konsumen yang tidak menanggapi iklan), bentuk ayam merupakan gambaran sebagai laki-laki tidak boleh malas harus seperti ayam. Seperti laki-laki, gambaran ayam tersebut menurut Rizky merupakan gambaran dari laki-laki yang tidak kenal takut dan gagah. Menurut pembuat logo, makna logo Brodo adalah implementasi dari dualismenya.

Founder Brodo ada dua orang, yang sama latar belakangnya namun meng-handle dua divisi yang bertolak belakang. Offense - defense, itulah inti dari sistem kerja Brodo. Hal ini yang menginspirasi designer untuk membuat logotype Brodo yang membentuk silhouette ayam jago yang bermakna pula logogram sehingga menghasilkan turunan makna baik yang bermacam-macam. 
Karena ayam adalah binatang yang punya asosiasi nilai yang banyak dan baik, pejantan, pekerja keras, bangun pagi, gagah dan binatang tropis khas Indonesia. Berdasarkan pernyataan diatas dapat dikatakan bahwa bentuk silhouette ayam jago pada logo Brodo memiliki turunan makna baik yang bermacam-macam. Dideskripsikan sebagai nilai yang baik, pejantan, pekerja keras,gagah dan ciri khas Indonesia. dilihat dari teori semiotika Roland Barthes maka dapat dijelaskan berdasarkan tanda visual dengan bantuan kode hermeneutik. Kode visual hermeneutik terlihat pada silhouette ayam jago. Visual silhouette tersebut merupakan gambaran dari filosofi Brodo yang diambil dari bahasa Itali yang berarti kaldu. Kaldu dimetaforasikan sebagai sepatu dengan cita rasa yang baik. Mitos dari silhouette tersebut adalah ayam jago yang menandakan tentang kejantanan, pekerja keras, gagah, dan cirri khas dari Indonesia. Sesuai dengan Brodo yang menjual produk footwear khusus pria dan berasal dari Indonesia.

\section{c. Latar Belakang Berwarna}

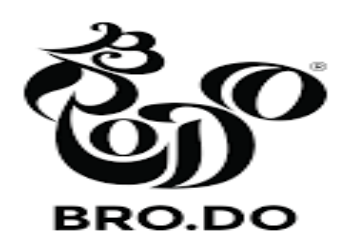

Sumber: google

\section{Gambar3. Latar Belakang Logo}

Tabel 3. Latar Belakang

\begin{tabular}{|c|l|l|}
\hline Detosasi & \multicolumn{1}{|c|}{ Konotasi } & \multicolumn{1}{c|}{ Mitos } \\
\hline Latar belakang & Warna putih adalah & 1. Kesucian \\
berwarna putih & kesetaraan, keadilan dan & 2. Kemurnian \\
& $\begin{array}{l}\text { menyiratkan ketidak } \\
\text { berpihakan, netralitas dan } \\
\text { independensi. Ini }\end{array}$ & $\begin{array}{l}\text { 3. Bersih } \\
\text { 4. Netral }\end{array}$ \\
\hline
\end{tabular}




\section{PEkspresi}

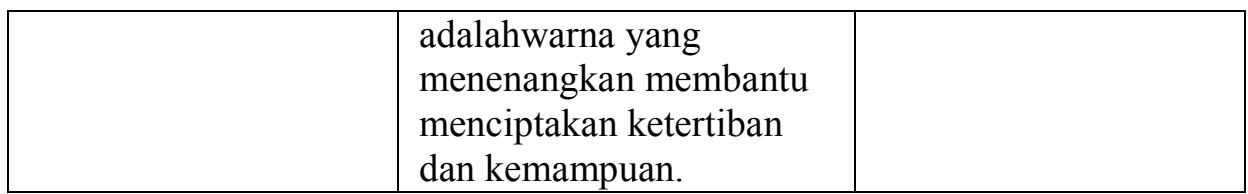

Mengenai latar belakang, Eko Suharjanto (konsumen yang menanggapi iklan) menyebutkan jika latar belakang putih merupakan warna netral yang dapat masuk kemana saja. Karena font Brodo berwarna hitam, maka warna putih dirasacocok untuk menetralisir font berwarna hitam yang melambangkan ketegasan. Sedangkan menurut Sobri Ikhsan (konsumen yang kurang menanggapi iklan), warna putih pada background logo Brodo bermakna bersih.

Menurut Rizky Ristianto (konsumen yang tidak menanggapi iklan), latar belakang warna putih bermakna netral. Menurut pembuat logo, latar belakang logo untuk mengangkat logo ketika diaplikasikan di media yang visualisasinya jenuh (latar belakang ramai) agar logo dapat tampil denganbaik danjelas. Latar belakang berwarna putih memiliki kesan yang sederhana dan mudah untuk bergabung dengan warna lainnya. Berdasarkan pernyataan di atas dapat ditarik kesimpulan bahwa warna putih pada latar belakang logo Brodo menggambarkan kesederhanaan produk Brodo dan keserasiannya untuk digunakan dengan warna lainnya dalam fashion seharihari. Setiap warna memiliki karakter dan arti yang berbeda-beda, menyesuaikan dengan kepribadian setiap individu.

Pada logo Brodo ini latar belakang yang digunakan berwarna putih, menurut teori Schiffman dan Kanuk (2008, hlm. 126) warna putih merupakan warna yang memiliki hubungan kepribadian yang berkaitan kebaikan, kesucian, kebersihan, dan kemurnian. Lalu untuk pengertian pemasarannya warna putih menunjukkan memberi kesan produk yang sederhana dan mudah dipadukan dengan warna lain.

Peneliti menganalisis bahwa putih merupakan warna yang melambangkan kebaikan dan kemurnian, selain itu menurut peneliti warna putih agar terlihat kontras dengan teks Brodo. Berdasarkan konsep warna yang dipilih dengan hubungan kepribadian dapat dilihat warna putih pada visual latar belakang merujuk pada hubungan kepribadian mengenai kemurnian. Makna yang 


\section{PERSERESSI}

Volume 1 Nomor 1. Juli - Desember 2018

terkandung pada visual latar belakang berwarna putih adalah upaya Brodo menyampaikan tentang keberadaan produk yang murni, sederhana dan sangat cocok dan mudah untuk digunakan jika dipadukan dengan warna lain.

\section{d. Teks Berwarna Hitam}

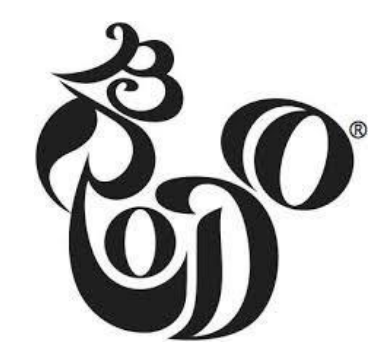

Sumber: Google

Gambar 4. Teks Brodo

Tabel 4. Teks Brodo

\begin{tabular}{|l|l|ll|}
\hline \multicolumn{2}{|c|}{ Denotasi } & \multicolumn{1}{|c|}{ Konotasi } & \multicolumn{2}{|c|}{ Mitos } \\
\hline $\begin{array}{l}\text { Teks } \\
\text { hitam }\end{array}$ & Berwarna & Warna hitam & 1. Kekuatan \\
& melambangkan kekuatan, & 2. Elegan \\
& elegan. Warna hitam & 3. Kekuasaan \\
& merupakan kekuatan dan & 4. Formal \\
& kekuasaan; warna ini sering & 5. Elegan \\
& dipakai untuk & 6. Bergensi \\
& menyampaikan kesan & \\
& formal, elegan, dan & \\
& bergensi (sepatu kulit & \\
& hitam, dasi hitam, & \\
& Mercedes hitam, kacamata & \\
& hitam) & \\
& & \\
\hline
\end{tabular}

Sebagai produk pria yang gentlemen, menurut Eko Suharjanto (konsumen yang menanggapi iklan) teks berwarna hitam melambangkan sesuatu yang gentlemen, tegas dan elegant. Cukup menggambarkan produk Brodo sebagai produk laki-laki. Serupa dengan Eko Suharjanto, Sobri Ikhsan (konsumen yang kurang menanggapi iklan) juga berpendapat demikian dan 


\section{PESRSESI}

menurut Sobri jika warna teks bukan hitam, akan mengurangi kejantanan produk Brodo. Karena menurutnya, laki-laki identik dengan warna yang gelap seperti hitam. Rizky Ristianto (konsumen yang tidak menanggapi iklan) juga berpendapat bahwa warna hitam adalah warna laki-laki, menggambarkan sesuatu yanggentlemen.

Menurut pembuat logo, teks berwarna hitam melambangkan ketegasan, kekuatan dan keperkasaan serta kesederhanaan. Berdasarkan pernyataan diatas, warna hitam menunjukan sesuatu yang tegas, kuat tetapi tetap sederhana. Menggambarkan produk yang dihasilkan oleh Brodo cocok untuk laki-laki yang ingin terlihatgentlemen.

Informasi yang di dapat dari pembuat design logo Brodo Footwear pesan yang ingin disampaikan adalah logo tersebut memiliki filosofi tersendiri. Dimana setiap bentuk, warna, dan tulisan dari logo memiliki arti tersendiri yang berkaitan dengan produknya. Secara keseluruhan hasil penelitian ini adalah logo Brodo Footwear menceritakan harapan dan cita-cita sang pemilik, yakni sewaktu membeli Brodo, customer tidak hanya membeli sebuah produk, tetapi sebuah mimpi, sebuah ide, sebuah gagasan bahwa anak muda Indonesia, selalu punya solusi yang lebih baik. Industri lokal pasti bisa bersaing dengan luar negeri Saat brand lain memutuskan untuk mengurangi kualitas dan mengurangi harga, Brodo memilih untuk menaikkan kualitas dan menaikkan harga. Brodo tidak ingin berakhir seperti brand lain yang bertarung di harga murah.

Peneliti juga melakukan wawancara kepada beberapa masyarakat (informan) yaitu tiga orang konsumen Brodo Footwear. Dengan kriteria menanggapi iklan Brodo Footwear, kurang menanggapi, dan tidak menanggapi. Menurut mereka logo tersebut menarik, karena logo nya begitu sederhana namun mudah di ingat dan unik. Menurut mereka icon tersebut dapat dijadikan brand identity di masyarakat, sebab logo Brodo begitu mudah diingat. Dapat dilihat bahwa logo Brodo merupakan satu bentuk teks Brodo yang fontnya diukir dan membentuk silhouette ayam jago. Mereka akan mengenali bahwa icon tersebut 


\section{PERSEREPSI}

merupakan bagian dari logo Brodo Footwear. Berdasarkan hasil analisis yang dilakukan oleh peneliti dan informasi yang didapat dari pembuat desain logo Brodo Footwear bahwa makna dari logo ini adalah menggunakan typography yang dibuat sendiri oleh designer Brodo Footwear secara manual/free hand dan komputerisasi yang melambangkan bahwa tulisan pada logo BrodoFootwear menggambarkan kesan elegan dan gentlemen.

Menggunakan latar belakang berwarna putih sebagai clean area atau juga sebagai stoping power agar logo type dan logo gram terlihat jelas. dan warna putih sendiri memiliki kesan sederhana, dan keserasian. Serta menggunakan warna tulisan hitam, bisa diartikan semua yang berbau hitam melambangkan kesan ketegasan, kekuatan dan keperkasaan serta kesederhanaan. Jenis huruf yang digunakan adalah jenis huruf yang tidak memiliki garis-garis kecil dan bersifat solid. Jenis huruf seperti ini lebih tegas, bersifat fungsional dan lebih modern. logo Brodo Footwear menggambarkan bentuk siluete ayam jago. Makna denotasi untuk keseluruhan yang terkandung dalam logo Brodo Footwear adalah teks ukiran Brodo dengan font yang membentuk seperti ayam jago berwarna hitam dengan background putih. Sedangkan makna konotasinya adalah tulisan yang begitu simpel dan unik dan memberi kesan laki-laki karena berbentuk ayam jago, dimana ayam jago selalu terlihat gagah. Teks tersebut merupakan penggambaran dari produk yang dibuat Brodo Footwear, dan mitosnya adalah produk Brodo Footwear dibuat khusus untuk pria yang gagah, dinamis dan elegant.

\section{SIMPULAN}

Secara keseluruhan logo Brodo memenuhi kriteria atau syarat sebuah logo bagi perusahaan. Logo tersebut sudah mewakili image perusahaan. Simbol yang dibuat sedemikian rupa sehingga membentuk logo yang mewakili apa yang ingin disampaikan oleh Brodo. Berdasarkan dari hasil penelitian tentang logo Brodo melalui pendekatan teori semiotika Roland Barthes maka peneliti dapat 


\section{PERSERESSI}

menyimpulkan, yaitu: Logo Brodo ingin memperlihatkan bahwa logo tersebut cerminan dari pendiri Brodo. Selain itu logo tersebut mempunyai makna tentang filosofi dari arti nama Brodo yang diambil dari bahasa Italy yaitu kaldu. Kaldu dimetaforsikan sebagai produk yang dihasilkan Brodo memiliki cita rasa. Silhouette ayam jago yang menggambarkan image kejantanan, ketangguhan dan ciri khas Indonesia. Ayam jago yang menurut banyak orang memiliki makna kejantanan dan kegagahannya menjelaskan tentang Brodo yang memiliki image gentlemen. Ada pula harapan dan cita-cita dari Brodo yang menginginkan Brodo Gentlemen Footwear untuk menjadi produk lokal yang dapat menginspirasi seluruh laki-laki di dunia dengan disimbolkan lingkaran yang tidak terputus.

Elemenfisik dan nonfisik yang ada di dalam logo Brodo adalah: Element fisik Bentuk dari logo Brodo secara keseluruhan Lingkaran. Warna yang ada pada logo yaitu hitam dan putih. Teks yang terdapat di fisik logo yaitu "Brodo" yang dibuat dengan menggunakan font gotham dan menggunakan warna dasar hitam pada tulisan Brodo sedangkan warna putih pada background logo. Elemen non fisik yang ada pada logo Brodo adalah mempunyai tujuan bahwa saat konsumen melihat logo tersebut akan selalu ingat cita rasa produk kebanggan Indonesia, dan kegagahan produk Brodo.

Dalam penelitian ini sesuai dengan teori semiotika Roland Barthes maka di dapat makna yang terkandung dalam logo Brodo. Makna denotasi yang terkandung dalam logo Brodo adalah silhouette ayam jago yang dibentuk dari teks "Brodo". Sedangkan makna konotasinya adalah cita rasa dalam fashion yang di dasari dengan sifat kejantanan dan ketegasan tetapi dalam tampilan yang sederhana dan penuh harapan dan ciri khas dari Indonesia. Mitosnya adalah Brodo sangat pantas digunakan oleh pria.

\section{REFERENSI}

Alex.Sobur.2009.Analisis Teks Media. Remaja Rosdakarya: Bandung.

Barthes, Roland. 2009. Mitologi Kreasi. Wacana: Yogjakarta. 


\section{PEkRSESE SI}

Volume 1 Nomor 1. Juli - Desember 2018

Juju, Dominikus. 2007. Dreamweaper CS3. PT Elex Media Kompitindo:Jakarta.

Juju, Dominikus dan Matamaya Studio. 2009. Fun with Symbian. PT Elex Media Komputindo:Jakarta.

Kusrianto, Adi. 2009. Pengantar Desain Komunikasi Visual. ANDI: Yogyakarta.

Rustan, Surianto.2009.Mendesign Logo.PTGramedia Pustaka Utama:Jakarta.

Sarosa, Samiadi.2012.Penelitian Kualitatif. PT Indeks:Jakarta.

Schiffman dan Kanuk.2008.Perilaku konsumen,Edisi 7.Indeks:Jakarta.

Suyanto.2007.Marketing Strategy Top Brand Indonesia.Andi:Yogyakarta.

\section{BIODATA PENULIS}

Canditra Sultannata lahir di Jakarta, 03 Juni 1991, lulus SMAN 1 Ciputat pada 2009, dan menjadi mahasiswa Program Studi Ilmu Komunikasi Fakultas Ilmu Sosial dan Ilmu Politik (FISIP) Universitas Pembangunan Nasional (UPN) Veteran Jakarta pada 2009, kini bekerja di Perusahaan Periklanan di Jakarta Selatan.

Siti Maryam, merupakan dosen program studi Ilmu Komunikasi Fakultas Ilmu Sosial dan Ilmu Politik Universitas Pembangunan Nasional Veteran Jakarta (FISIP UPNVJ). Selain mengajar, pernah menjabat sebagai Ketua Program Studi Ilmu Komunikasi dan kini menjabat sebagai Wakil Dekan 1 FISIP UPNVJ. 